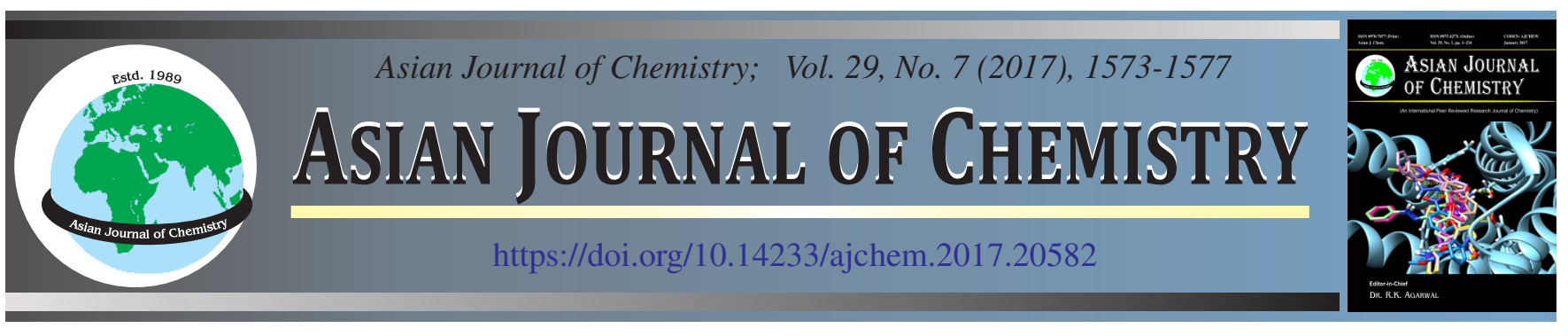

\title{
Synchronised Separation of Antihypertensive, Antidiabetic and Antihyperlipidemic Drugs by RP-HPLC
}

\author{
Monika $^{1, *}$, Pooja Chawla ${ }^{2}$ and Shailendra Pandey ${ }^{3}$
}

${ }^{1}$ Department of Pharmaceutical Chemistry, School of Pharmacy, Babu Banarasi Das University, Faizabad Road, Lucknow-226 028, India ${ }^{2}$ Department of Pharmaceutical Chemistry, Roorkee College of Pharmacy, Roorkee-247 667, India

${ }^{3}$ Department of Pharmacy, Sarojini Naidu Medical College, Agra-282 002, India

*Corresponding author: Fax: +91 562 2260353; E-mail: spandey.rs.phe@iitbhu.ac.in

\begin{abstract}
A new simple, rapid and precise reverse phase isocratic HPLC method has been developed for estimation of pioglitazone, amlodipine, atorvastatin and clopidogrel simultaneously. The separation was achieved on a Millenium M-Sil C18 (125 mm $\times 4.6 \mathrm{~mm})$ column using a mobile phase comprising of methanol:0.02 $\mathrm{M} \mathrm{KH}_{2} \mathrm{PO}_{4}$ (65:35) and $\mathrm{pH}$ adjusted 4.5 with $0.01 \%$ orthophosphoric acid. Stocks and dilutions were prepared in mobile phase. The flow rate was kept at $1 \mathrm{~mL} / \mathrm{min}$ and analytes were screened with a UV detector. The retention time of pioglitazone, amlodipine, atorvastatin and clopidogrel were 3.17, 4.05, 6.09 and 13.73 min, respectively. The method was validated according to ICH guidelines with respect to linearity, accuracy, precision and specificity. The linearity range was found to be 0.625 to $10 \mu \mathrm{g} / \mathrm{mL}$ for all drugs. The limit of detection of pioglitazone, amlodipine, atorvastatin and clopidogrel were $0.11,0.03,0.048$ and 0.14 , respectively and limit of quantitation were $0.34,0.10,0.14$ and $0.43 \mu \mathrm{g} / \mathrm{mL}$. The method was validated as a final confirmation of method development with respect to its linearity, precision, accuracy, ruggedness and robustness. This validated method can be handy for the evaluation of various commercially available pharmaceutical dosage forms with high precision and reproducibility.
\end{abstract}

Keywords: Pioglitazone, Amlodipine, Atorvastatin, Clopidogrel, Method development, Validation, Isocratic separation.

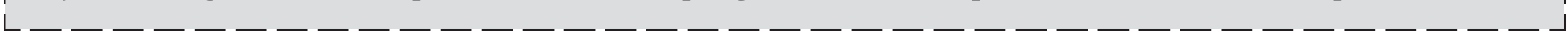

\section{INTRODUCTION}

Pioglitazone (P) is 5-[[4-[2-(methyl-2-pyridinylamino)ethoxyphenyl]methyl]-2,4-thiazolidinedion used in the treatment of type-2 diabetes mellitus (also known as non-insulin dependent diabetes mellitus [1,2] (NIDDM) or adultonset diabetes) (Fig. 1). It stimulates the peroxisome proliferatoractivated receptor gamma (PPAR- $\gamma$ ) and to a lesser extent PPAR- $\alpha$. Pioglitazone modulates the transcription of the insulin-sensitive genes involved in the control of glucose and lipid metabolism in the muscle, adipose tissue and in the liver. Various methods have been reported for the assay of pioglitazone alone or its combination with other drugs including HPLC in pharmaceutical formulations and in biological fluids [1-3], High performance thin layer chromatography (HPTLC) [4], spectrophotometry [5] and LCMS/MS [6]. Amlodipine (AM) 2-[(2-aminoethoxy)methyl]-4-(2-chlorophenyl)-3ethoxycarbonyl-5-methoxycarbonyl-6-methyl-1,4-dihydropyridine, is a calcium channel blocker. It inhibits the trans membrane influx of calcium ions into vascular smooth muscle and muscles and cardiac muscles (Fig. 2). Several methods including HPLC [7,8], high performance thin layer chromato- graphy (HPTLC) [9], spectrophotometry [10] and LCMS/MS [11] have been reported for the assay of amlodipine. Atorvastatin (AT) $(3 R, 5 R)-7$-[2-(4-fluorophenyl)-3-phenyl-4-(phenylcarbamoyl)-5-propan-2-ylpyrrol-1-yl]-3,5-dihydroxyheptanoic acid is a drug that inhibits the 3-hydroxyl-3- methylglutaryl coenzyme A (HMG-Co A) reductase enzyme that participates in the endogenous cholesterol synthesis, supporting its clinical use in the treatment of hypercholesterolemia (Fig. 3). Literature survey revealed that several methods like HPLC in pharmaceutical dosage form [12-14], HPLC in human serum [15], HPTLC [16] and LC-MS [17] have been reported for determination of atorvastatin. Clopidogrel hydrogen sulphate (CP) methyl (2S)-(2-chlorophenyl)[6,7-dihydrothieno[3,2c]pyridin-5(4H)-yl]acetate sulphate (Fig. 4), is an oral, thienopyridine-class antiplatelet agent used to inhibit blood clots in a variety of conditions such as coronary artery disease, peripheral vascular disease, cerebrovascular disease and to prevent myocardial infarction. The drug is an irreversible inhibitor of the P2Y12 adenosine diphosphate receptor found on the membranes of platelet cells. Clopidogrel specifically and irreversibly inhibits the P2Y12 subtype of ADP receptor, which is important in aggregation of platelets and cross-linking 


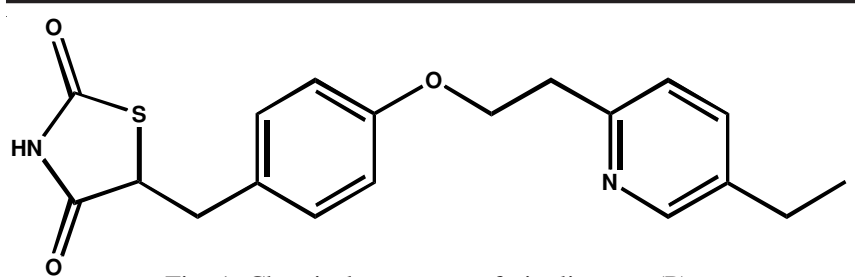

Fig. 1. Chemical structures of pioglitazone (P)<smiles>CCOC(=O)C1=C(COCCN)NC(C)=C(C(=O)OC)C1c1ccccc1Cl</smiles>

Fig. 2. Chemical structures of amlodipine (AM)

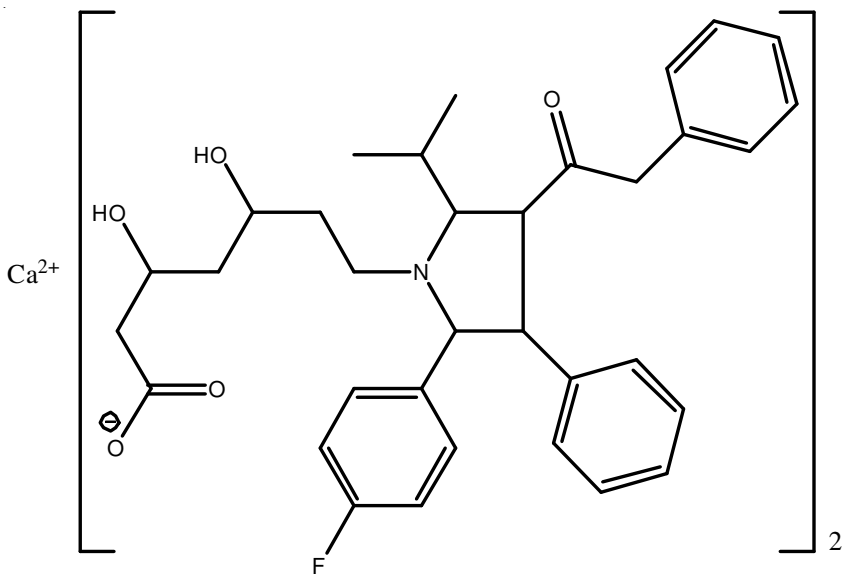

Fig. 3. Chemical structures of atorvastatin (AT)

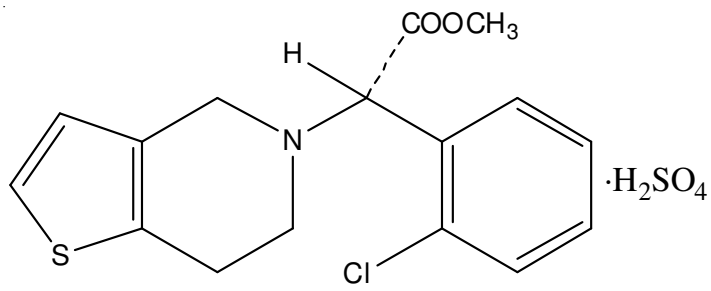

Fig. 4. Chemical structures of clopidodrel (CP)

by the protein fibrin.Various analytical methods involving HPLC [18,19], LC-MS [20] and LC-MS/MS [21] have been reported for the analysis of clopidogrel.

To date, no HPLC method is available for the simultaneous estimation of pioglitazone, amlodipine, atorvastatin and clopidogrel in tablet dosage form, which prompted to pursue the present work. Simultaneous determination of pioglitazone, amlodipine, atorvastatin and clopidogrel remains difficult using single mode of separation due to their different physicochemical properties and polarities. To the best of our knowledge, this is the first time that all four analytes were estimated simultaneously with isocratic mode. This work holds a challenge for developing a new method in high performance liquid chromatography to elute four analyte with isocratic mode with reduced elution time. The use of isocratic mode for separation of analytes make the method more economic because the main disadvantages of gradient mode is high cost, as two pumps are needed and the generation of column back pressure which arise during the mixing of solvents. In present study all the analyte were eluted using simple mobile phase and completely avoid acetonitrile. The limitations of acetonitrile are: expensive, toxic and generate air bubbles when mixed with water. On the other hand methanol is inexpensive, less toxic in comparison to acetonitrile, methanol is more polar than acetonitrile and reducing the risks of solid buffer precipitation. So the uses of methanol in mobile phase make the method more economic in comparison to existing methods. The cost-effectiveness, use of isocratic elution and simplicity of the assay make it an attractive procedure in HPLC. Here we report a rapid and sensitive method for the identification and quantitation of four drugs (pioglitazone, amlodipine, atorvastatin calcium, clopidogrel bisulfate) using isocratic reverse phase high-performance liquid chromatography with UV detector. Hence, the objective of this work was to develop a simple, precise, accurate, reliable and rapid high performance liquid chromatographic analytical method for simultaneous estimation of pioglitazone, amlodipine, atorvastatin and clopidogrel and to validate the method in accordance with $\mathrm{ICH}$ [22,23] guidelines.

\section{EXPERIMENTAL}

The HPLC system (Shimadzu, Tokyo, Japan) consisting of pump LC-10 atorvastatin, variable length UV visible detector SPD-10A and a manual rheodyne injector 77251 fitted with $20 \mu \mathrm{L}$ was used for the entire analysis. Analysis was performed on a Millenium M Sil $\mathrm{C}_{18}$ of $125 \times 4.6 \mathrm{~mm}$ id, $5 \mu \mathrm{m}$ particle analytical column at ambient temperature. Chromatographic data were recorded and processed using a Sphinchrom Chromatographic Station @CRF Version 1.7 (Sphinchrom Pvt. Ltd., Chennai, India).

Pure analytical standards of pioglitazone, amlodipine, atorvastatin and clopidogrel were procured as a gift samples from Alkem Laboratories, Gurgoan, India. Tablets of pioglitazone (P-GLIT-15, Cipla, India) amlodipine (Amlip, $5 \mathrm{mg}$, Cipla, India), atorvastatin (Atrolip, $5 \mathrm{mg}$, Cipla India) and clopidogrel (Ceruvin, $75 \mathrm{mg}$, Ranbaxy India) were procured from retail pharmacy. HPLC grade methanol and water were procured from S.D. Fine Chem. Ltd. (India). AR grade orthophosphoric acid (85\%) was procured from Merck Limited, Mumbai (India).

Standards preparation: Mobile phase composition was methanol: $0.02 \mathrm{M} \mathrm{KH}_{2} \mathrm{PO}_{4}(65: 35 \% \mathrm{v} / \mathrm{v})$ and the $\mathrm{pH}$ was adjusted to 4.5 with $0.01 \%$ orthophosphoric acid. Individual stock solution of pioglitazone $(1 \mathrm{mg} / \mathrm{mL})$, amlodipine $(1 \mathrm{mg} / \mathrm{mL})$, atorvastatin $(1 \mathrm{mg} / \mathrm{mL})$ and clopidogrel $(1 \mathrm{mg} / \mathrm{mL})$ were prepared in methanol. Working standard of individual and mixtures were prepared in mobile phase over a concentration range of 0.625 $10 \mu \mathrm{g} / \mathrm{mL}$ for all drugs. All standards were stored at $2-8{ }^{\circ} \mathrm{C}$ and were found to be stable during the period of study, which were brought to room temperature before use. 
Preparation of sample solutions: Twenty tablets of each drug were weighed, their mean weight determined and crushed individually to a fine homogenous powder. Quantity equivalent to $15 \mathrm{mg}$ of pioglitazone, $5 \mathrm{mg}$ of amlodipine, $5 \mathrm{mg}$ of atorvastatin and $5 \mathrm{mg}$ of clopidogrel were transferred separately into $10 \mathrm{~mL}$ volumetric flask and dissolved in mobile phase and volume made upto $10 \mathrm{~mL}$ and sonicated for $20 \mathrm{~min}$. The resulting solutions were centrifuged at $1000 \mathrm{rpm}$ for $30 \mathrm{~min}$ and clear supernatant $(1 \mathrm{~mL})$ containing suitable amount of drug was taken from the above filtered solutions and diluted upto 10 $\mathrm{mL}$ with mobile phase $(100 \mu \mathrm{g} / \mathrm{mL})$, working standards were prepared with mobile phase. The results are presented in Table-1.

\begin{tabular}{lccc}
\multicolumn{4}{c}{ TABLE-1 } \\
\multicolumn{4}{c}{ ANALYSIS OF FORMULATIONS } \\
\hline Drug & $\begin{array}{c}\text { Quantity claimed } \\
(\mathrm{mg} / \text { tablet })\end{array}$ & $\begin{array}{c}\text { Quantity found } \\
(\mathrm{mg} / \text { tablet })\end{array}$ & $\begin{array}{c}\text { Recovery } \\
(\%)^{*}\end{array}$ \\
\hline Pioglitazone & 15 & 15.40 & 102.67 \\
Amlodipine & 05 & 05.18 & 103.6 \\
Atorvastatin & 05 & 05.06 & 101.2 \\
Clopidogrel & 75 & 75.08 & 101.10 \\
\hline *Recovery $(\%)=95-105 \%$. & &
\end{tabular}

\section{RESULTS AND DISCUSSION}

Method development and optimization: The chromatographic separation was best achieved on a reverse phase Millenium M Sil $\mathrm{C}_{18}(125 \times 4.6 \mathrm{~mm}$ id, $5 \mu \mathrm{m})$ column. Various mobile phases consisting of acetonitrile: methanol:water at different $\mathrm{pH}$, were studied for the simultaneous isocratic elution of all the components. Finally, the mobile phase consisting of methanol:0.02 $\mathrm{M} \mathrm{KH}_{2} \mathrm{PO}_{4}(65: 35 \% \mathrm{v} / \mathrm{v})$ and $\mathrm{pH}$ adjusted to 4.5 with orthophosphoric acid was found to provide adequate peak separation. The flow rate was $1 \mathrm{~mL} / \mathrm{min}$, with an injection volume of $20 \mu \mathrm{L}$. The wavelength was maintained $238 \mathrm{~nm}$ for better peak height. Retention time of the drugs obtained under these condition were 3.17, 4.05, 6.09 and $13.70 \mathrm{~min}$ for pioglitazone, amlodipine, atorvastatin and clopidogrel, respectively. The typical chromatogram of the sample is shown in Fig. 5 and the results are given in Table-2.

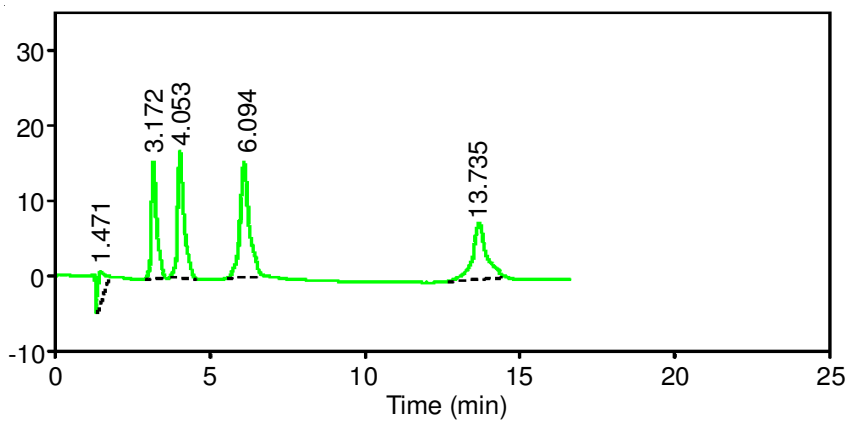

Fig. 5. Typical chromatogram of standard solution of pioglitazone, amlodipine, atorvastatin and clopidogrel
TABLE-2

OPTIMIZED CHROMATOGRAPHIC CONDITIONS OF PIOGLITAZONE, AMLODIPINE, ATORVASTATIN AND CLOPIDOGREL BY PROPOSED HPLC METHOD

\begin{tabular}{ll}
\hline \multicolumn{1}{c}{ Parameter } & \multicolumn{1}{c}{ Optimized condition } \\
\hline Mobile phase & $\begin{array}{l}\text { Methanol: } 0.02 \mathrm{M} \mathrm{KH}_{2} \mathrm{PO}_{4} 65: 35 \% \\
\text { v/v and } \mathrm{pH} \text { were adjusted to } 4.5 \mathrm{with}\end{array}$ \\
& $0.01 \%$ orthophosphoric acid \\
& $\mathrm{C}_{18}$, Millenium M.Sil Limited, \\
Column & Length-12.5 cm, i.d.-4.6 mm \\
& $\mathrm{UV}$ at $238 \mathrm{~nm}$ \\
Detection & $1 \mathrm{~mL} / \mathrm{min}$ \\
Flow rate & Room temperature \\
Temperature & $3.17 \mathrm{~min}$ \\
Retention time of pioglitazone & $4.05 \mathrm{~min}$ \\
Retention time of amlodipine & $6.09 \mathrm{~min}$ \\
Retention time of atorvastatin & $13.73 \mathrm{~min}$ \\
Retention time of clopidogrel &
\end{tabular}

The system suitability was carried out after the method development and validation have been completed. A system suitability test, according to USP, was performed on the chromatograms obtained from standard and test solutions to check different parameters and the results obtained from six replicate injections of the standard solutions are summarized in Table-3.

Method validation: Method validation was carried out according to ICH (Q2) guidelines with respect to linearity, accuracy, precision, limit of detection (LOD) and limit of quantification (LOQ).

Linearity: The response was measured as peak area. The calibration curve obtained by plotting peak area $(\mathrm{mV} / \mathrm{s})$ against concentration $(\mu \mathrm{g} / \mathrm{mL})$ showed linearity in the concentration range of 0.625 to $10 \mu \mathrm{g} / \mathrm{mL}$ for all drugs. The linear regression equation of pioglitazone, amlodipine, atorvastatin and clopidogrel were found to be $y=35.01 x-1.170, y=50.773 x-2.1822$, $\mathrm{y}=60.99 \mathrm{x}-0.610$ and $\mathrm{y}=46.069 \mathrm{x}+1.8588$, respectively and the regression coefficient values were found to be 0.9999 , 0.9998, 0.9999 and 0.9999, respectively. These results indicating high degree of linearity of all drugs. The curves followed Beer's Law in the range of 0.625 to $10 \mu \mathrm{g} / \mathrm{mL}$ for all drugs. The regression statistics are shown in Table-4.

Specificity: A representative chromatogram (Fig. 6) indicates that commonly used tablet excipients did not interfere with the method and no significant changes in retention times of the drugs were observed in the presence and absence of excipients.

Precision and accuracy: Recoveries (\%) and relative standard deviations (RSD, \%) values were used to express accuracy and precision. For assessment of intra-day variability, standard solutions were analyzed within one day (morning, afternoon and evening) and for inter-day variability, the same were analyzed for 14 days. The intra-and inter-day precision were carried out at three different concentration level i.e. 0.625 , 2.5 and $10 \mu \mathrm{g} / \mathrm{mL}$ for pioglitazone, amlodipine, atorvastatin and clopidogrel, respectively. The low level of $\%$ RSD for

\begin{tabular}{|c|c|c|c|c|}
\hline \multicolumn{5}{|c|}{$\begin{array}{c}\text { TABLE-3 } \\
\text { SYSTEM SUITABILITY PARAMETERS }\end{array}$} \\
\hline Parameters & Pioglitazone & Amlodipine & Atorvastatin & Clopidogrel \\
\hline Resolution & - & 2.8 & 5.3 & 14.0 \\
\hline Asymmetric factor & 1.5 & 1.5 & 1.4 & 1.1 \\
\hline Theoretical plates & 1859 & 2429 & 3046 & 7235 \\
\hline
\end{tabular}




\begin{tabular}{lcccc}
\hline \multicolumn{5}{c}{ TABLE-4 } \\
\multicolumn{1}{c}{ LINEARITY STUDY } \\
\hline Parameters & Pioglitazone & Amlodipine & Atorvastatin & Clopidogrel \\
\hline Linearity range $(\mu \mathrm{g} / \mathrm{mL})$ & $0.625-10$ & $0.625-10$ & $0.625-10$ & $0.625-10$ \\
Correlation coefficients $\left(\mathrm{r}^{2}\right)$ & 0.9999 & 0.9998 & 0.9999 & 0.9999 \\
Regression equation & $\mathrm{y}=35.01 \mathrm{x}-1.170$ & $\mathrm{y}=50.773 \mathrm{x}-2.1822$ & $\mathrm{y}=660.99 \mathrm{x}-0.610$ & $\mathrm{y}=46.069 \mathrm{x}+1.8588$ \\
Slope $(\mathrm{m})$ & 35.01 & 50.773 & 60.99 & 46.069 \\
Intercept $(\mathrm{c})$ & 1.170 & 2.1822 & 0.610 & 1.8588 \\
\hline$* \mathrm{y}=\mathrm{mx}+\mathrm{c}, \mathrm{y}=$ peak response, $\mathrm{m}=$ slope, $\mathrm{x}=$ concentration $(\mathrm{mg} / \mathrm{mL}), \mathrm{c}=$ intercept. & &
\end{tabular}

TABLE-5

INTRA- AND INTER-DAY PRECISION AND ACCURACY DATA OF PIOGLITAZONE, AMLODIPINE, ATORVASTATIN AND CLOPIDOGREL

\begin{tabular}{lccc}
\hline \multicolumn{1}{c}{ Parameters } & Pioglitazone & Amlodipine & Atorvastatin \\
\hline Intra-day \% RSD 2.5 $(\mu \mathrm{g} / \mathrm{mL})$ & 0.59 & 0.88 & 0.56 \\
Inter-day \% RSD 2.5 $(\mu \mathrm{g} / \mathrm{mL})$ & 0.50 & 1.0 & 0.88 \\
\% Accuracy intra-day $(2.5 \mu \mathrm{g} / \mathrm{mL})$ & -0.58 & -0.27 & -1.11 \\
\% Accuracy inter-day $(2.5 \mu \mathrm{g} / \mathrm{mL})$ & +0.66 & +0.13 & -0.67 \\
\hline Average of six determination, RSD is relative standard deviation & & +0.77 & +0.53 \\
\hline
\end{tabular}

Average of six determination, RSD is relative standard deviation.

\begin{tabular}{|c|c|c|c|c|c|c|c|c|}
\hline \multirow[b]{3}{*}{ Parameters } & \multicolumn{6}{|c|}{$\begin{array}{c}\text { TABLE-6 } \\
\text { ROBUSTNESS RESULTS FOR THE RP-HPLC METHOD }\end{array}$} & & \\
\hline & \multicolumn{2}{|c|}{ Pioglitazone } & \multicolumn{2}{|c|}{ Amlodipine } & \multicolumn{2}{|c|}{ Atorvastatin } & \multicolumn{2}{|c|}{ Clopidogrel } \\
\hline & $\begin{array}{l}\text { Retention } \\
\text { time (min) }\end{array}$ & $\operatorname{RSD}(\%)$ & $\begin{array}{l}\text { Retention } \\
\text { time (min) }\end{array}$ & $\operatorname{RSD}(\%)$ & $\begin{array}{l}\text { Retention } \\
\text { time (min) } \\
\end{array}$ & $\operatorname{RSD}(\%)$ & $\begin{array}{l}\text { Retention } \\
\text { time (min) } \\
\end{array}$ & $\operatorname{RSD}(\%)$ \\
\hline \multicolumn{9}{|l|}{ Flow rate $(\mathrm{mL} / \mathrm{min})$} \\
\hline 0.9 & 3.3 & 0.64 & 4.3 & 0.45 & 6.2 & 0.78 & 14.1 & 1.20 \\
\hline 1.1 & 2.9 & 0.59 & 3.7 & 0.39 & 5.8 & 0.80 & 13.0 & 1.07 \\
\hline \multicolumn{9}{|l|}{$\mathrm{pH}$} \\
\hline 4.6 & 3.1 & 0.24 & 3.9 & 0.64 & 6.01 & 1.33 & 13.6 & 0.44 \\
\hline 5.0 & 3.0 & 0.27 & 4.1 & 0.57 & 5.9 & 1.38 & 13.7 & 0.43 \\
\hline \multicolumn{9}{|c|}{ Change in organic conc. } \\
\hline$-2 \%$ & 3.1 & 0.64 & 4.05 & 1.04 & 6.09 & 0.49 & 13.72 & 0.82 \\
\hline$+2 \%$ & 3.1 & 0.65 & 4.03 & 1.03 & 6.06 & 0.48 & 13.70 & 0.84 \\
\hline
\end{tabular}

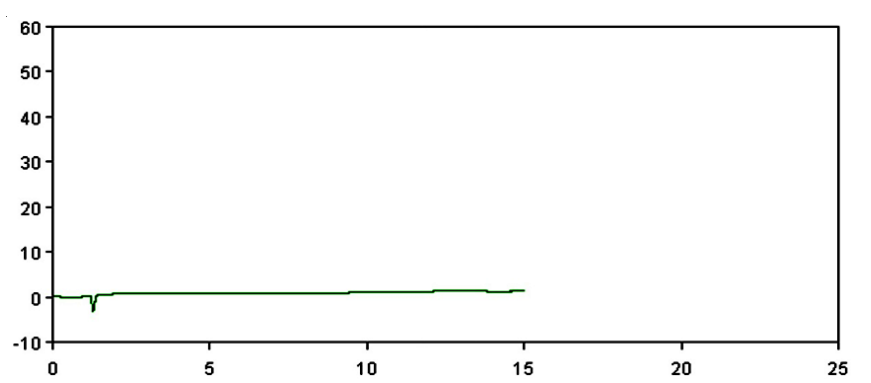

Fig. 6. Chromatogram of blank sample (mobile phase)

intra-and inter-day reveal that method is precise. Results of accuracy and precision were presented in Table-5.

Sensitivity: Limit of detection (LOD) and limit of quantification (LOQ) were calculated using formula LOD = $3.3(\sigma / \mathrm{s})$ and $\mathrm{LOQ}=10(\sigma / \mathrm{s})$; here $(\mathrm{s})$ is slope of the calibration curve and $\sigma$ is standard deviation of the response. LOD of pioglitazone, amlodipine, atorvastatin and clopidogrel were $0.11,0.03,0.048$ and 0.14 , respectively and LOQ were 0.34 , $0.10,0.14$ and $0.43 \mu \mathrm{g} / \mathrm{mL}$, respectively.

Robustness: The method robustness was performed by evaluating the influence of small changes in chromatographic conditions, such as flow rate $( \pm 0.1 \mathrm{~mL} / \mathrm{min})$, organic content in mobile phase $( \pm 2 \%)$ and $\mathrm{pH}$ ( \pm 0.2 units). The conditions with the variation and the results are presented in Table-6.

\section{ACKNOWLEDGEMENTS}

The authors thank Dr. R.C. Gupta, Emeritus Scientist, Central Drugs Research Institute, Lucknow, India for his valuable suggestions and Prof. Rajiv Gupta, Dean, School of Pharmacy Babu Banarasi Das University, Lucknow, India for providing facilities to carry out the research work.

\section{REFERENCES}

1. B.L. Kolte, B.B. Raut, A.A. Deo, M.A. Bagool and D.B. Shinde, J. Chromatogr. Sci., 42, 70 (2004); https://doi.org/10.1093/chromsci/42.2.70.

2. A. Karthik, G. Subramanian, M.C. Rao, K. Bhat, R.A. Kumar, P. Musmade, M. Surulivelrajan, K. Karthikeyan and N. Udupan, Pak. J. Pharm. Sci., 21, 421 (2008).

3. P. Sripalakit, P. Neamhom and A. Saraphanchotiwitthaya, J. Chromatogr. B Analyt. Technol. Biomed. Life Sci., 843, 164 (2006); https://doi.org/10.1016/j.jchromb.2006.05.032.

4. D. Singh, S.C. Dwivedi and A. Kushnoor, Int. J. Biol. Adv. Res., 2, 171 (2010).

5. P. Shakya and K. Singh, Int. J. Pharm. Sci. Res., 11, 153 (2010).

6. Z.H. Lin, W. Ji, D. Desai-Krieger and L. Shum, J. Pharm. Biomed. Anal., 33, 101 (2003); https://doi.org/10.1016/S0731-7085(03)00344-3. 
7. S.-Y. Dai, S.-T. Qiu, W. Wu and C.-M. Fu, J. Pharm. Anal., 3, 440 (2013); https://doi.org/10.1016/j.jpha.2013.09.002.

8. Q. Yu, Z.-Y. Hu, F.-Y. Zhu, J.-H. Zhu, L.-L. Wan, Y. Li and C. Guo, J. Chromatogr. A, 73, 257 (2011); https://doi.org/10.1007/s10337-010-1883-4.

9. B.G.Chaudhri, N.M. Patel and P.B. Shah, Indian Drugs, 43, 645 (2006).

10. P. Mishra, A. Gupta and K. Shah, Indian J. Pharm. Sci., 69, 831 (2007); https://doi.org/10.4103/0250-474X.39446.

11. R. Dhiman, V. Durga and K.M. Meetei, J. Bioanal. Biomed., 7, 91 (2015).

12. D. Jain, N. Jain and R. Raghuwanshi, Indian J. Pharm. Sci., 70, 263 (2008); https://doi.org/10.4103/0250-474X.41473.

13. H.M. Hafez, A.E. Abdullah, L.M. Abdelaziz and M.M. Kamal, J. Chromatogr. Sep. Technol., 5, 1 (2014).

14. H.M. Hafez, A.A. Elshanawany, L.M. Abdelaziz and M.S. Mohram, Pharm. Anal. Acta, 5, 1 (2014)

15. Y. Shah, Z. Iqbal, L. Ahmad, A. Khan, M.I. Khan, S. Nazir and F. Nasir, J. Chromatogr. B Analyt. Technol. Biomed. Life Sci., 879, 557 (2011); https://doi.org/10.1016/j.jchromb.2011.01.004.

16. D. Nagavalli, B. Srinivas and K.C. Chakravarthi, J. Pharm. Biomed. Sci., 4, 1 (2010).
17. Y. Zhou, J. Li, X. He, M. Jia, M. Liu, H. Li, Z. Xiong, Y. Fan and W. Li, J. Pharm. Biomed. Anal., 83, 101 (2013); https://doi.org/10.1016/j.jpba.2013.04.021.

18. A. Robinson, J. Hillis, C. Neal and A.C. Leary, J. Chromatogr. B Analyt. Technol. Biomed. Life Sci., 848, 344 (2007); https://doi.org/10.1016/j.jchromb.2006.10.076.

19. L. Silvestro, M.C. Gheorghe, I. Tarcomnicu, S. Savu, S.R. Savu, A. Iordachescu and C. Dulea, J. Chromatogr. B Analyt. Technol. Biomed. Life Sci., 878, 3134 (2010); https://doi.org/10.1016/j.jchromb.2010.09.022.

20. H. Ksycinska, P. Rudzki and M. Bukowska-Kiliszek, J. Pharm. Biomed. Anal., 41, 533 (2006); https://doi.org/10.1016/j.jpba.2005.11.035.

21. M. Takahashi, H. Pang, K. Kawabata, N.A. Farid and A. Kurihara, J. Pharm. Biomed. Anal., 48, 1219 (2008); https://doi.org/10.1016/j.jpba.2008.08.020.

22. ICH Guidelines: Validation of Analytical Procedures: Q2B (1996).

23. ICH Guidelines: Validation of Analytical Procedures: Q2A (1994). 